\title{
WOULD REDUCING TENURE PROBABILITIES INCREASE FACULTY SALARIES?
}

\author{
Ronald G. Ehrenberg \\ Paul J. Pieper \\ Rachel A. Willis
}

Working Paper No. 5150

\section{NATIONAL BUREAU OF ECONOMIC RESEARCH 1050 Massachusetts Avenue \\ Cambridge, MA 02138 June 1995}

We are grateful to C. Elton Hinshaw, Secretary-Treasurer of the American Economic Association for granting us access to individual institutional responses to the AEA's annual salary survey of economics departments, to Charles Scott at Loyola College (Maryland) for providing the data to us, to Kari Alexander for research assistance, and to Daniel Hamermesh for his comments on a preliminary draft. Because of confidentiality requirements, these data cannot be made available to other researchers for replication purposes. This paper is part of NBER's research program in Labor Studies. Any opinions expressed are those of the authors and not those of the National Bureau of Economic Research.

() 1995 by Ronald G. Ehrenberg, Paul J. Pieper, and Rachel A. Willis. All rights reserved. Short sections of text, not to exceed two paragraphs, may be quoted without explicit permission provided that full credit, including $\odot$ notice, is given to the source. 


\title{
WOULD REDUCING TENURE \\ PROBABILITIES INCREASE \\ FACULTY SALARIES?
}

\begin{abstract}
The simplest competitive labor market model asserts that if tenure is a desirable job characteristic for professors, they should be willing to pay for it by accepting lower salaries. Conversely, if an institution unilaterally reduces the probability that its assistant professors receive tenure, it will have to pay higher salaries to attract new faculty.

Our paper tests this theory using data on salary offers accepted by new assistant professors at economics departments in the United States during the 1974-75 to 1980-81 period, along with data on the proportion of new Ph.Ds hired by each department between 1970 and 1980 that ultimately received tenure in the department or at a comparable or higher quality department. We find evidence that a tradeoff did exist. Equally important, departments that offer low tenure probabilities to assistant professors also paid higher salaries to their tenured faculty. We attribute this to their need to pay higher salaries to attract tenured faculty from the external market.

Ronald G. Ehrenberg

New York State School of Industrial and Labor Relations Cornell University Ithaca, NY 14853-3901 and NBER

Paul J. Pieper

Department of Economics

University of Illinois

Chicago, IL 60607-7121

Rachel A. Willis

Department of Economics University of North Carolina Chapel Hill, NC 27599
\end{abstract}




\section{Introduction}

Rising tuition levels in American private colleges and universities that have far exceeded the rate of inflation for over a decade have increasingly brought these institutions under close public scrutiny and led to calls for their increased efficiency and accountability. These pressures have been exacerbated by a number of factors, including the abolition of mandatory retirement for faculty that became effective in January 1994. The end of mandatory retirement has led to fears that colleges and universities will become increasingly populated by an aged nonproductive heavily tenured professoriate whose relatively high salaries will place increased financial burdens on institutions and whose failure to retire at reasonable ages will reduce the ability of institutions to diversify their faculty along race, gender, and ethnic lines. ${ }^{1}$ In fact, during the 1994-95 academic year, 64.3 percent of all full-time college and university faculty members in the United States had tenured appointments. ${ }^{2}$

Economists have provided a variety of explanations, in addition to traditional academic freedom ones, to justify a tenure system. These include that by providing a form of job security for tenured faculty, the system encourages senior faculty to share their knowledge with younger colleagues and to hire as colleagues those younger applicants who they perceive to be most talented, that it serves as a "tournament" that provides an incentive for both nontenured and tenured faculty to work harder than would otherwise be the case, and that it solves the incentive problem needed to get talented people to obtain very specialized and expensive training that may be useful only in well-defined and narrowly specialized tasks. ${ }^{3}$ In addition, the fact that tenure is typically accompanied by increasing salaries over the life-cycle, even though there is 
evidence that productivity eventually declines with age, can be rationalized as part of a life-cycle incentive compensation scheme that provides incentives for both nontenured and tenured faculty to exert more effort than otherwise would be the case. ${ }^{4}$

However, the abolition of mandatory retirement for college and university faculty has caused many people (primarily outside of academia) to focus on tenure's costs. Proposals to eliminate or modify tenure have been put forth and one institution recently unilaterally eliminated tenure for its faculty. Absent from the discussion of these proposals has been an awareness of the simplest competitive labor market model that asserts that if tenure is a desirable job characteristic for professors, they should be willing to pay for it, by accepting lower salaries. ${ }^{6}$ Conversely, according to this theory, a reduction in tenure probabilities should reduce the attractiveness of faculty positions and thus increase the salaries necessary to attract people into doctoral study and academia.

Would the abolition of tenure, or a reduction in the tenure probabilities that new assistant professors at an institution face, increase that institution's costs for new faculty? This paper first addresses this issue. It uses salary offers accepted by new assistant professors at economics departments in United States colleges and universities during the 1974-75 to 1980-81 period, along with data on the proportions of new Ph.D.s hired by each department between 1970 and 1980 that ultimately received tenure in the department or at a comparable or higher quality department, to estimate if a trade-off did exist between starting salaries and tenure probabilities during the 1970s.

A tradeoff may also exist, however, between the tenure probabilities faced by assistant professors and the salaries a department pays to tenured faculty. Ceteris 
paribus, lower tenure probabilities for assistant professors imply either that a department will have fewer tenured faculty in steady state or that it will hire a greater share of its tenured faculty from faculty already employed at other institutions. Faculty hired away from other institutions typically earn higher salaries than those promoted from within because the former must be compensated for their monetary and psychological cost of mobility and induced to leave their original institution. ${ }^{8} 19$

To the extent that lower tenure probabilities for assistant professors do imply that a greater share of tenured faculty were hired away from other institutions, one should therefore also expect to observe higher salaries for tenured faculty in this situation, other factors held constant. We address this issue by using the AEA data, which also contained information on average salary by rank for economics department faculty, to estimate if a tradeoff did exist between average salaries of tenured faculty and the tenure probabilities offered new assistant professors during the 1970s.

To motivate the empirical work that follows, the next section presents a simple conceptual model of the salary/tenure probability relationship. Section III presents descriptive statistics on the starting salaries paid to assistant professor of economics during the 1974-1980 period and estimates of the tenure probabilities they faced. Our empirical estimates of the starting salary/tenure probability relationship appears in Section IV. Section V briefly discusses the relationship between the tenure probabilities faced by new assistant professors in a department and the salaries of tenured faculty in the department. Empirical estimates are provided that indicate that low tenure probabilities may require an institution to also pay more for tenured faculty. Finally, the 
paper ends with a discussion of our findings and the directions in which future research might proceed.

\section{A Simple Conceptual Model of the Trade-Off Between Tenure Probabilities and Starting Salaries in Academia}

To motivate the empirical research, consider the following simple conceptual model. Risk-neutral new Ph.D.s, who are all of equal quality, are confronted with job offers from universities of equal quality? ${ }^{9}$ These offers vary only in their peçuniary compensation and their probability of receiving tenure. Individuals are assumed to have professional careers that last $\mathbf{N}$ periods and the tenure decision is made at each institution after a probationary period of $\mathbf{P}$ years.

During the probationary period an individual is assumed to receive a fixed salary per period of $W_{p i}$ at institution $i$ and to receive a benefit package at that institution which increases her compensation by a multiple $b_{i}(>1)$. The individual believes that the probability of receiving tenure at institution $i$ is $T_{i}$ and that if she receives tenure, her salary per period will be increased by a multiple $g_{i}(>1)$ to the level $W_{T i}=W_{P_{i}} g_{i}$, which will then remain constant for the remainder of her worklife. If the individual fails to receive tenure, she will receive a lower compensation package in alternative employment of $C\left(C<W_{T}\right)$. Finally, for simplicity, voluntary mobility actoss institutions is ignored; if the individual receives tenure, she is assumed to remain with the institution throughout her career. 
Given these assumptions, the individual's expected present value of compensation if she chooses employment initially at university $i$ is

$$
V=\int_{0}^{P} W_{\mathrm{P}} b_{i} e^{-\pi} d t+\int_{P}^{N}\left(\left(T_{i} W_{\mathrm{P}} b_{B_{i}}\right)+\left(1-T_{\mathrm{i}}\right) c\right) e^{-\pi t} d t
$$

or

$$
V=\frac{W_{P_{i}} b_{i}}{r}\left[\left(1-e^{-\mathrm{rP}}\right)+T_{B_{i}}\left(e^{-r P}-e^{-r N}\right)\right]+\frac{\left(1-T_{i}\right) c}{r}\left(e^{-\mathrm{rP}}-e^{-r \mathrm{r}}\right)
$$

If individuals care only about their expected present value of compensation, an . assumption which is relaxed in the empirical work, then in equilibrium, the expected present value of compensation must be equal at all institutions for equal "quality" faculty. Setting V equal to a constant and differentiating, it is straightforward to show that

$$
\partial W_{\mathrm{Pi}} / \partial b_{\mathrm{i}}<0, \partial W_{\mathrm{i}} / \partial g_{\mathrm{i}}<0, \partial W_{\mathrm{i}} / \partial T_{\mathrm{i}}<0
$$

That is, ceteris paribus, institutions that offer more generous benefit packages, higher growth rates of earnings between the nontenured and tenured ranks, and higher probabilities of receiving tenure, will offer lower starting salaries.

\section{Descriptive Statistics}

Starting in the 1974-75 academic year, the American Economic Association (AEA) has conducted an annual survey of economics departments that requests information on the median starting salary offers accepted by new assistant professors. 
The AEA made the responses to these surveys available to us for the 1974-75 to $1980-81$ period under the restriction that the data be kept confidential.

Response rates for departments that offered only bachelors' or masters' degrees were not always high and many of these institutions were small and hired only a few faculty during the decade of the 1970s. The expost tenure probabilities that can be computed for these institutions (see below) would be based on a small number of observations and would be a very imperfect measure of the exante tenure probabilities that a new assistant professor faced. Hence, the analyses reported in this paper are confined to the doctorate granting departments, which numbered roughly 110 during the period.

Some of these departments, however, did not regularly respond to the AEA questionnaire. Moreover, in any one year, less than half of the departments actually made offers which were accepted at the new assistant professor level to individuals who were working on their dissertations but had yet to complete them (ABDs) or who had a Ph.D. in hand. For the seven-year period, we actually have data on 286 such offers to new assistant professors - roughly 40 a year. The 286 offers came from 86 different Ph.D. granting departments. ${ }^{10}$

Table 1 presents descriptive data on these starting salaries by year. As panel A indicates, the mean median accepted salary offer rose from $\$ 13,708$ in $1974-75$ to $\$ 20,081$ in 1980-81. The standard deviation of the offers in any year was small; less than $\$ 1,200$ in most years. Depending upon one's perspective, this might reflect a highly competitive market or one in which salary collusion was prevalent (prior to 1980 the departments 
also reported their planned offers for the next year and this information was distributed at the "chairmen's breakfast at the annual AEA meetings). It is this limited variability across institutions each year that our empirical research presented in the next section will seek to "explain". The small standard deviations do mask, however, the $\$ 5,000$ to $\$ 7,000$ range between the minimum and maximum offers that existed each year.

Each year approximately 20 to 25 percent of the offers went to individuals who had yet to complete their Ph.D.s (ABDs). Might some of the variation in any year simply reflect lower offers made to $\mathrm{ABDs}$ to provide an incentive for them to quickly complete their degrees? Panel B of Table 1 provides similar descriptive statistics for the subset of offers that went to individuals who had their Ph.D.s in hand by the start of their appointment. While the mean median offers are now marginally higher, neither the standard deviation nor the range of offers changes very much. Thus, while it will be important to control for whether an offer went to a person who had a degree in hand in our empirical analyses, this variable will most likely not explain most of the variability in offers across departments.

A key premise of our study is that tenure probabilities vary across institutions, so it is important to examine whether this is true. Information on the probability of achieving tenure for new Ph.D.s hired at each department comes from a database constructed by two of us, Willis and Pieper. ${ }^{11}$ This database includes information on over 1,400 individuals who both obtained a $\mathrm{Ph} . \mathrm{d}$. degree in economics from a United States department between 1970 and 1980 and also assumed a position as an assistant professor at a United States economics department that granted either masters or 
doctoral degrees. The annual doctoral degree list published in the American Economic Review is the source for the new economics Ph.D. data. This list was matched against the faculty positions reported in the Economic Institute's periodic Guide to Graduate Study in Economics to determine new assistant professor appointments. The Guide includes rank by employing institution for nearly all doctoral degree granting schools and a large number of master's degree granting schools. ${ }^{12}$ Sample members' academic employment histories were collected from later volumes of the Guide, supplemented by the American Economic Association's periodic Survey of Members and by college catalogues.

From these data, it is possible to compute four different measures of the proportion of newly hired assistant professors during the 1970-80 period in each department who ultimately received tenure at the department or at one of comparable or better quality. The first, TEN1, is the proportion of new assistant professors who received tenure at the institution or at another institution in the same "quality tier." Departmental equality is measured here by the Jones, et al. (1982) ranking of programs and the institutions are somewhat arbitrarily grouped into the following five tiers: 1 (ranks 1 to 6), 2 (ranks 7-15), 3 (ranks 16-29), 4 (ranks 30-47), and 5 (all other programs). ${ }^{13}$

The second, TEN2, is the proportion of new assistant professors who received tenure at the institution or at another institution in the same, or a better, quality tier. The third, TEN3, is the proportion who received tenure at the institution itself. Finally, TEN5 is the proportion who received tenure at the institution or a better ranked one; 
here the actual Jones, et al. ranking rather than the quality tier of the department is used in the comparisons.

TEN3 is the measure one typically thinks of when one thinks of a tenure probability. However, it is not necessarily the best measure to use in our empirical analyses. An institution that offers a .2 tenure probability at itself and a .3 probability of obtaining tenure at an equal or better quality institution may be viewed as equally or more attractive, other factors held constant, than a similar institution that offers only a .5 tenure probability at itself. Which tenure probability is the appropriate measure to use in empirical research is an open question.

In practice, as we shall see, it makes little difference because the four measures are very highly correlated across institutions. ${ }^{14}$ Table 2 presents descriptive statistics for the four tenure probability measures. Overall, the mean unweighted own tenure probability, TEN3, is .41 and has a standard deviation of .22. The alternative measures' means are only slightly larger; the largest being TEN2 at .5 . This suggests that individuals who start out at one institution, only infrequently find tenured positions at an equal or better quality institution.

When the institutions are broken down by tier, each of the tenure probability measures tends to increase as one moves from the highest quality to lowest quality tier. For example, the mean value of TEN3 is .33 at tier 1 departments but .45 at tier 5 departments. However, this inter-tier variation in mean tenure probabilities is small relative to the intra-tier variation across departments. Focusing on TEN3 again, this measure varies from .21 to .57 across the six tier 1 schools and the intra-tier standard 
deviation of TEN3 ranges from .13 to .25 across tiers. Hence, variations in tenure probabilities across institutions do not reflect primarily differences in institutional quality.

\section{Econometric Estimates: New Assistant Professor Salaries}

To test if a trade-off did exist between starting assistant professor salaries and tenure probabilities across economics departments during the 1974-75 to 1980-81 period, equations are estimated of the form

$$
W_{\mathrm{Pit}}=b_{0}+b_{1} T_{\mathrm{Pi}}+b_{2} b_{\mathrm{it}}+b_{3} g_{\mathrm{i}}+b_{1} X_{\mathrm{it}}+\epsilon_{\mathrm{it}}
$$

Here $\mathrm{W}_{\mathrm{Pit}}$ is the logarithm of department i's median starting salary for new assistant professors in year $t$ during the period, $\mathbf{T}_{\mathbf{i}}$ is the proportion of newly hired Ph.D.s in department $i$ during the period that received tenure at that institution or at an institution of equal or better quality, $b_{i t}$ is the faculty benefit rate at the institution in which department $i$ is located in year $t$, and $g_{i t}$ is the growth rate in salaries at department $i$ that occurs when tenure is received. This growth rate is empirically specified as the ratio of average associate professor to average assistant professor salaries in the department in year $t$.

The $\mathrm{X}_{i t}$ are a vector of other variables that are expected to influence starting salaries. The latter include estimates of the cost-of-living in the area in which the department is located as well as dichotomous year variables (since starting salaries vary over time), the quality tier of the institution, and the quality of the faculty that the department has hired, and whether the salary offer was to someone who had a Ph.D. in hand. 
Ceteris paribus, departments will have to pay higher salaries if they are located in high cost-of-living areas or if they want to attract high quality faculty. Conversely, ceteris paribus, higher quality departments can offer lower salaries because of the better nonpecuniary conditions of employment that they offer, such as lower teaching loads, better research support, and better colleagues and students. Faculty denied tenure at higher quality departments may also have better alternative employment opportunities than faculty denied tenure at lower quality departments, and this also will reduce the starting salary needed to attract faculty to the higher quality institutions. ${ }^{\text {is }}$

Cost-of-living differences across areas in each year are controlled for in the analyses reported here by the logarithm of the median value of owner-occupied housing in 1979 in the city in which the institution is located and the average combined state income and sales tax at a $\$ 20,000$ adjusted gross income (in 1979 dollars) in the state in which the institution is located. ${ }^{16}$ The faculty benefit rate at the institution is obtained for 1979-80, the first year that it was collected, from AAUP (1980). Not all institutions could be matched to housing value or benefit data and the sample used in the estimation that follows is reduced to 263 observations.

Table 3 presents the estimated salary equations for the four different tenure probability measures. Turning first to the "control variables," all have the anticipated signs. Higher benefit rates (BEN) are associated with lower starting salaries, while higher housing values (LMEDVAL) and higher state average income and sales tax rates (TAX) are associated with higher starting salaries. In each of these cases, the magnitude of the relationship is smaller (in absolute value) than the one-to-one relationships that 
one might expect. This may reflect measurement error, housing values and tax rates are only two components of cost-of-living and that the benefit rate on the average salary level is not perfectly correlated with the benefit rate on new assistant professor salaries.

As expected, those institutions in which the ratio of associate to assistant professor salaries are higher (RASSOC), pay lower starting salaries. Similarly, individuals with Ph.D.s in hand receive starting salaries that were roughly 3 percent higher than those individuals who were $\mathrm{ABD}$.

Attempts to control for the quality distribution of the faculty hired by the institution by including the shares of an institution's new hires coming from the various quality tiers of doctoral programs never yielded statistically significant results. In part, this occurred because the quality tier that an institution is in is highly correlated witb the quality tiers of the institutions from which it draws its faculty. In part, this occurred because the quality of say a Harvard $\mathrm{Ph} . \mathrm{D}$. who is hired at Yale, is very different from the quality of a Harvard Ph.D. who is hired at "Podunk."

The omission of new hire quality data means that the included tier dichotomous variables capture the net effect of both departmental quality and new hire quality on starting salaries. Only the coefficients for top tier schools are statistically significant and their negative coefficients imply that, other factors held constant, top tier schools pay between 7 and 8 percent less than other schools.

Turning to the variables of key interest to us, the tenure probability variables, the coefficient of each proves to be negative and statistically significant from zero. The models are marginally improved when the tenure probability is defined to include 
receiving tenure at an equal or better quality department (TEN2, TEN5) and perform the best when "better quality" is defined to be better ranked (TEN5) instead of better tier (TEN2).

In the preferred specification (column 4), reducing the tenure probability from the mean in the sample of roughly .5 (Table 2) to 0 , implies an increase in the starting salary for new assistant professors of roughly 3.4 percent. ${ }^{17}$ Similarly, reducing the tenure probability by .1 implies an increase in the starting salary of only 0.68 percent. While increases of these magnitudes may seem small, one should remembered that economics is a field with excellent employment opportunities in the nonacademic sector. As noted, in footnote 15, the compensating wage differential that must be paid for reduced tenure prospects will be smaller in this situation. In addition, the 1974-75 to $1980-81$ period was one of weak demand for faculty and real academic salaries declined during the period. ${ }^{18}$ Compensating wage differentials are likely to be smaller in such periods of excess supply for faculty than they are in periods in which the demand for faculty is stronger.

Several extensions warrant brief discussion here. First, when the model was estimated separately for $\mathrm{Ph} . \mathrm{D} . \mathrm{s}$ and $\mathrm{ABDs}$, the tenure probability coefficient was larger in absolute value for the ABD subsample. Given the time pressures they face in trying to complete dissertations and begin an academic career at the same time, ABDs are less likely than Ph.D.s to amass a substantial research record during their probationary period. Hence, they are the ones most likely to feel the adverse impact of low tenure probabilities and thus to receive the larger compensating wage differentials. 
Second, when the model was reestimated with the data stratified by higher (tiers 1 to 4) and lower (tier 5) quality departments, the tenure probability coefficient was largest in absolute value for the lower quality departments. Alternative employment opportunities in both the academic and nonacademic sectors are likely to be better for people denied tenure at the higher quality schools than for those denied tenure at the lower quality schools. Thus, it is at the lower quality schools that the compensating wage differentials for tenure probabilities will be larger.

Finally, when the model was reestimated with the data stratified by early (1974-75 to $1977-78$ ) and later (1978-79 to $1980-81$ ) years during the period, the tenure probability coefficient was larger in absolute value during the latter period and close to -.1 during that time. A few of the variables used in the empirical analyses are available only for the latter years in our sample (LMEDVAL, BEN, TAX) and the use of these latter years' values in the early years may induce considerable measurement error in estimates for the early years. Thus, it is likely that the "true" compensating wage differential for low tenure probabilities in Ph.D. economics departments in the 1970s is somewhat larger than those implied by the coefficients in Table 3.

\section{Econometric Estimates: Tenured Faculty Salaries}

Lower tenure probabilities for assistant professors imply either that a department will have fewer tenured faculty in steady state or that it will hire a greater share of its tenured faculty from faculty already employed at other institutions. Tenured faculty hired away from other institutions typically earn more than tenured faculty promoted 
from within because the former must be induced to leave their original institution and compensated for the monetary and psychological costs of mobility that they face.

To the extent that lower tenure probabilities for assistant professors do imply a greater share of tenured faculty hired from the external market, we should therefore expect to observe a negative relationship between assistant professors' tenure probabilities and the salaries of tenured faculty, in a department, other factors held constant. Moreover, the tenure probability measure most closely related to tenured faculty members' salaries in this case is likely to be TEN3, the probability of receiving tenure at the institution itself.

Panel A of Table 4 uses data from the AEA annual salary survey on average salaries for associate professors of economics to test this hypothesis. Equations similar to equation (4) are estimated, save that the logarithm of the average associate professor salary is now the dependent variable and that the new $\mathrm{Ph}$.D. variable (PHD) and the ratio of average associate to average assistant professor salaries (RASSOC) are excluded from the analyses. The coefficients for the various tenure probability variables are found in panel $\mathrm{A}$ of the table.

Quite strikingly, lower tenure probabilities for assistant professors are associated, other factors held constant, with higher salaries for associate professors, and TEN3 is the best performing tenure probability variable. Reducing TEN3 from its mean in the sample of roughly .4 (Table 2) to 0 , implies an increase in the average associate professor salary of roughly 5 percent. Similarly, reducing this tenure probability by .1 , implies an increase in the average salary of associate professors of roughly 1.2 percent. 
Lower tenure probabilities for assistant professors in a department thus lead to increases in both new assistant professor and average associate professor salaries. ${ }^{19}$

Of course, these analyses suggest that the estimates in Table 3, which treat the ratio of average associate to average assistant professor salaries as predetermined may overstate the extent to which changes in tenure probabilities influence new assistant professor salaries. To see why this is true, panel B of Table 4 shows the tenure probability coefficients that result when the ratio of average associate to average assistant professor salaries (RASSOC) was regressed on each tenure probability and a set . of year and tier dichotomous variables. In each case, the tenure probability coefficient is negative, implying that higher tenure probabilities imply lower growth rates of salary across ranks.

Returning to equation (4), it is straightforward to show that

$$
\partial W_{\mathrm{Pit}} / \partial T_{\mathrm{Pi}}=b_{1}+b_{3} \partial g_{i} / \partial T_{\mathrm{Pi}}
$$

where $g_{i}$ equals RASSOC. Since $b_{3}$ is always less than zero in Table 3 , it follows that the tenure probability coefficients in Table 3 overstate (in absolute value), the magnitude of the tradeoff between new assistant professor salaries and the tenure probabilities that they face.

Put another way, the cost to an economics department of unilaterally reducing the tenure probability that its assistant professors faced during the 1970s was not primarily the higher salaries that it had to pay to attract new assistant professors. Rather, it was the higher salaries it had to pay for the tenured faculty members that it hired from the external market. 


\section{Concluding Remarks and Extensions}

The analyses of the previous sections provided estimates of the likely impact on starting faculty salaries and tenured faculty salaries at institutions that unilaterally decide to substantially reduce the probabilities that new assistant professors ultimately receive tenure at them, if only a small number of institutions make such changes. However, analyses of this type can not provide any evidence on what the likely impact of substantially changing the average probability (across institutions) of a new assistant professor's receiving tenure would be on the average salary that academic institutions must pay. To answer the latter question requires evidence on how changes in average tenure probabilities influence the distribution of new Ph.D.s between the nonacademic and academic sectors and how they affect the willingness of potential Ph.D. students to embark upon and complete Ph.D. study.

While a number of empirical studies have addressed the determinants of the supply of new doctorates in the aggregate (see the summary in Ehrenberg (1992)) and a smaller number have addressed the decisions by new Ph.D.s whether to accept employment in the academic or nonacademic sectors (e.g., Hansen, et al. (1990), Stapleton (1989), Freeman (1975)), none have addressed the role of tenure probabilities in these decisions. Future research should attempt to conceptualize more fully the role that tenure probabilities play in influencing the aggregate supply of new Ph.D.s, the allocation of these $\mathrm{Ph} . \mathrm{D} . \mathrm{s}$ across academic and nonacademic employment and academic salary levels and then, if possible, to estimate these relationships. 
It would also be worthwhile for researchers to replicate the analyses described above for a field which has less promising nonacademic employment opportunities than does economics. One would expect to find compensating wage differentials for tenure probabilities higher in fields with poorer nonacademic employment opportunities. That is, the estimates presented in this paper may well understate the impact of changing tenure probabilities in fields with less promising nonacademic employment opportunities. Finally, our estimates used salary data for the 1974-75 to 1980-81 period. This period was dictated by the availability of tenure probability data and the willingness of the AEA to provide us with salary data. However, this was a period of excess supply in the academic labor market and, as noted above, real academic salaries fell during the periods. Compensating wage differentials for undesirable job characteristics, such as low tenure probabilities, are likely to be smaller in periods of excess supply than they are in periods of tight labor markets. Thus, our estimates will likely understate the impact of changing tenure probabilities in periods when the labor market for faculty are tight, such as has been projected by some for the years ahead. ${ }^{20}$ 


\section{Footnotes}

1. That these fears may not be justified is discussed by Rees and Smith (1991) and Hammond and Morgan (1991) who evaluate the likely effect of the abolition of mandatory retirement on faculty retirement rates, and by Hamermesh (1994), Rees and Smith, Levin and Stephan (1991), and Stephan and Levin (1992) who study and summarize studies of life-cycle faculty productivity differentials.

2. See American Association of University Professors (1995), Table 12.

3. See, for example, Stigler (1984), Carmichael (1988), Rosen and Lazear (1981), McPherson and Winston (1993), and Siow (1994).

4. Lazear (1979). The incentive for tenured faculty to exert more effort than would otherwise be the case follows in this model from tenure being an implicit contract which at best provides a promise that nominal salaries will not be reduced. "Nonperformers" thus face the possibility of zero nominal salary increases and their real salaries being reduced each period by the rate of inflation.

5. Henderson (1994) and Bennett (1994).

6. This theory, which goes back at least to Adam Smith is summarized in Ehrenberg and Smith (1994), Chapter 8.

7. As will become clear below, the sample period is dictated by data availability.

8. For evidence that tenured faculty hired from the outside tend to earn more than tenured faculty promoted from within, see Ransom (1993).

9. Institutional and individual quality differences will be accounted for in the empirical analyses. 
10. These departments are listed in Appendix Table 1A.

11. See Willis (1990) and Willis and Pieper (1992).

12. College catalogs and the job announcement section of the American Economic Review were used by Willis and Pieper to obtain new hires at institutions that were not included in an issue of the Guide.

13. Willis and Pieper (1992) provides an empirical justification for these groupings.

14. The lowest pairwise correlation is .92 .

15. In terms of equation 2, $c$ will be higher at high quality institutions and it is straightforward to show that $\partial \mathrm{W}_{\mathrm{Pi}_{\mathrm{i}}} / \partial \mathrm{c}<0$.

16. The average state tax rate data come from Feenberg and Rosen (1986) who compute and present these rates for the 1977-1983 period. We used their 1977 rates for the $1974-75$ to $1977-78$ data and their 1978,1979 , and 1980 rates, respectively, for data from the next three academic years.

17. When we tested whether the marginal "implicit price" for tenure probabilities varied with the initial level of the tenure probability by including a quadratic tenure probability term in the model, the quadratic term never proved significant. Thus, the assumption of only a linear effect implicit in (4) seems reasonable.

18. See American Association of University Professors (1995).

19. A similar tradeoff does not appear in these data between the average salary of full professors in a department and the tenure probabilities faced by assistant professors. We believe that this is due to measurement error problems induced by our inability to control for differences in the seniority distribution of full professors across departments. 
This is less of a problem with the data on the average salaries of associate professors, since most people spend less than six years in this rank.

20. See, for example, Bowen and Sosa (1989). 


\section{References}

American Association of University Professors (1980). The Annual Report on the Economic Status of the Profession," Academe 66: 285-307.

American Association of University Professors (1995), "A Ray of Sunshine," Academe 81: 8-31.

American Chamber of Commerce Research Association (1982). Inter-City Cost of Living Index (Indianapolis, IN: ACCRA).

Benneth, Amanda (1994). "Many Decry It, Few Deny It," Wall Street Joumal, October 10.

Barron's Educational Series (1982). Barron's Profiles of American Colleges, 13th ed. (Great Neck, NY: Barron's).

Bowen, William G. and Julie Ann Sosa (1989). Prospects for Faculty in the Arts and Sciences (Princeton, NJ: Princeton University Press).

Carmichael, Lorne (1988). "Incentives in Academia: Why Is There Tenure?," Joumal of Political Economy 96: 453-72.

Clark, David E. and Thomas A. Knapp (forthcoming). The Hedonic Price Structure of Faculty Compensation at U.S. Colleges and Universities," Review of Regional Studies.

Ehrenberg, Ronald G. (1992). "The Flow of New Doctorates," Joumal of Economic Literature 30: 830-75.

Ehrenberg, Ronald G. and Robert S. Smith (1994). Modern Labor Economics: Theory and Public Policy, 5th ed. (New York: Harper Collins).

Feenberg, Daniel R. and Harvey S. Rosen (1986). "State Personal Income and Sales Taxes, 1977-1983." In Harvey Rosen, ed., Studies in State and Local Public Finance (Chicago: University of Chicago Press).

Hamermesh, Daniel S. (1994). "Aging and Productivity, Rationality and Matching: Evidence from Economists." National Bureau of Economic Research Working Paper No. 4906 (Cambridge, MA).

Hammond, P. Brett and Harriet P. Morgan, eds. (1991). Ending Mandatory Retirement for Tenured Faculty: The Consequences for Higher Education (Washington, DC: National Academy Press). 
Henderson, Keith (1994). "Bennington Remakes Itself Decisively," Christian Science Monitor, August 29.

Jones, Lyle V., Gardner Lindzey, and Porter E. Coggeshall, eds., (1987). An Assessment of Reseanch - Doctorate Programs in the United States (Washington, DC: National Academy Press).

Lazear, Edward (1979). "Why Is There Mandatory Retirement?," Joumal of Political Economy 87: 1261-85.

Lazear, Edward and Sherwin Rosen (1981). "Rank Order Tournaments as Optimum Labor Contracts," Joumal of Political Economy 89: 841-65.

Levin, Sharon G. and Paula E. Stephan (1991). 'Research Productivity Over the Life Cycle: Evidence for Academic Scientists," American Economic Review 81: 114132.

McPherson, Michael and Gordon Winston (1993). The Economics of Academic Tenure: A Relational Perspective" in Michael McPherson, Morton Schapiro, and Gordon Winston, eds., Paying the Piper: Productivity, Incentives, and Financing in U.S. Higher Education (Ann Arbor, MI: University of Michigan Press).

Ransom, Michael R. (1993). "Seniority and Monopsony in the Academic Labor Market," American Economic Review 83: 221-233.

Rees, Albert and Sharon Smith (1991). Faculty Retirement in the Arts and Sciences (Princeton, NJ: Princeton University Press).

Siow, Aloysius (1994). "The Organization of the Market for Professors" (mimeo, University of Toronto Economics Department).

Stephan, Paula and Sharon G. Levin (1992). Strilaing the Mother Lode in Science: The Importance of Age, Place, and Time (New York: Oxford University Press).

Stigler, George (1984). "An Economic Episode" in George Stigler, The Intellectual and the Market Place (Cambridge, MA: Harvard University Press).

U.S. Bureau of the Census (1983). County and City Data Book (Washington, DC: Government Printing Office).

U.S. Bureau of Labor Statistics (1979). Handbook of Labor Statistics (Washington, DC: Government Printing Office). 
Willis, Rachel A. (1990). Academic Labor Markets: A Study of Academic Placement and Tenure for Doctoral Economists (Evanston, IL: Northwestern University Ph.D. Dissertation).

Willis, Rachel A. and Paul J. Pieper (1993). "Gender Differences in Promotion for Academic Economists." Paper presented at the Western Economic Association Conference, June, Lake Tahoe, Nevada. 
Table 1

Startiog Salaries for New Asabtant Professors of Economics at Ph.D. Granting Institutions

\begin{tabular}{|c|c|c|c|c|c|c|c|c|}
\hline \multirow[b]{2}{*}{ Year } & \multicolumn{4}{|c|}{$\begin{array}{c}\text { (A) } \\
\text { A. New Asbatant Professors }\end{array}$} & \multicolumn{4}{|c|}{$\begin{array}{c}\text { (B) } \\
\text { Those With PLD. }\end{array}$} \\
\hline & $\mathbf{a}$ & Mean (Std. Der.) & Mhe. & Max. & $\mathbf{n}$ & Mean (Std. Der.) & Min. & Max. \\
\hline $1974-75$ & 45 & 13,758 (1106) & 10,636 & 16,500 & 36 & $13,766(1214)$ & 10,636 & 16,500 \\
\hline $1975-76$ & 34 & 14,544 (11T) & 12,375 & 17,500 & 25 & $14,711(1220)$ & 12,375 & 17,500 \\
\hline $1976-77$ & 44 & $15,456(1000)$ & 14,000 & 18,000 & 35 & $15,539(1000)$ & 14,000 & 18,000 \\
\hline $1977-78$ & 43 & $16,147(1149)$ & 13,419 & 19,450 & 36 & $16,197(1218)$ & 13,419 & 19,450 \\
\hline $1978-79$ & 40 & 16,963 (1067) & 15,000 & 20,000 & 29 & 17,144 (1174) & 15,000 & 20,000 \\
\hline $1979-80$ & 39 & 18,465 (1253) & 16,500 & 21,500 & 29 & $18,627(1308)$ & 16,500 & 21,500 \\
\hline $1990-81$ & 41 & $20,081(1623)$ & 17,500 & 24,000 & 32 & 20,437 (1591) & 17,500 & 24,000 \\
\hline
\end{tabular}

where $n$ is the number of institutions' starting salary offers reported. If an institution made offers to individuals both with and without Ph.D.s in a year, the institution would show up twice in Panel A in the year.

Source: Authors' calculations from institutional responses to the American Economics Association's Amnual Survey of Economic Departments, $1974-75$ to $1980-81$ 
Table 2

Alternattve Tenure Probability Measurea at Ph.D. Granting Decucomico Departineats

Faced by New Assistant Professers Dering the 1970-80 Period

\begin{tabular}{|c|c|c|c|c|c|c|}
\hline \multirow{2}{*}{$\begin{array}{l}\text { Tearie } \\
\text { Probabillity } \\
\text { Mesoure }\end{array}$} & \multicolumn{6}{|c|}{ Mean (Std. Der.) [MIn./Max.] } \\
\hline & AII & $\operatorname{Tex} 1$ & Ther 2 & Ther 3 & Ther 4 & Ther 5 \\
\hline TEN1 & $.46(22)[0 / 1]$ & $.37(.11)[.25 / .57]$ & $.41(.18)[.20 / .51]$ & $.40(.16)[.17 / .69]$ & $.44(50)[.14 / 81]$ & $50(25)[0 / 1]$ \\
\hline TEN2 & $50(.220[0 / 1]$ & $.37(.11)[.25 / .51]$ & $.44(.17)[.20 / .67]$ & $.44(.17)[.17 / .97]$ & $.48(.19)[.14 / .88]$ & $54(.25)[0 / 1]$ \\
\hline TEN3 & $.41(22)[0 / 1]$ & $.33(.13)[.21 / .57]$ & $.35(.14)[.17 / .57]$ & $37(.14)[.17 / .62]$ & $.41(.18)[.14 / 81]$ & $.45(25)[0 / 1]$ \\
\hline TEN5 & $.47(22)[0 / 1]$ & $36(.12)[.21 / 57]$ & $.40(.16)[.21 / .62]$ & $.43(.17)[.17 / .77]$ & $.46(.19)[.14 / .88]$ & $51(.65)[0 / 1]$ \\
\hline $\mathbf{n}$ & 104 & 6 & 9 & 14 & 18 & 57 \\
\hline
\end{tabular}

where

TEN1 - proportion of the $1970-1960$ new assistant professors who received tenure at the institution or another instivtion in the same tier

TEN2 - proportion of the 1970-1980 new assistant professors who received tenure at the institution or at another institution in the same or better tier

TEN3 - proportion of the 1970-1980 mew assistant professors who received tenure at the institution

TEN5 - proportion of the 1970-1980 new assistant professors who received tenure at the institution of at a better ranked institution

Source: Authore computations from data on the careers of economists who received Ph.Ds from American univenities between 1970 and 1980 and then became assistant professors. See Willis (1990) and Willis and Pieper (1992) for details. 
Determinants of the Logarithm of New Assistant Professor of Economics Starting Salaries at Ph.D. Granting Institutions: American Economlc Assoclation 1974-75 to 1980-81 Sample

(absolute value $t$ statistics)

\begin{tabular}{|c|c|c|c|c|}
\hline & (1) & (2) & (3) & (4) \\
\hline TEN1 & $-.052(2.2)$ & & & \\
\hline TEN2 & & $-.060(2.6)$ & & \\
\hline TEN3 & & & $-.052(2.2)$ & \\
\hline TENS & & & & $-.068(3.0)$ \\
\hline BEN & $-.004(4.3)$ &. $.004(4.2)$ &. $.004(4.0)$ &. $.004(4.0)$ \\
\hline RASSOC & $-214(5.5)$ & $-.215(5.6)$ & $-220(5.5)$ & $-.222(5.7)$ \\
\hline PHD & $.037(4.0)$ & $.037(4.0)$ & $.038(4.0)$ & $.037(4.0)$ \\
\hline LMEDVAL & $.029(2.6)$ & $.029(2.6)$ & $.028(2.5)$ & $.029(2.7)$ \\
\hline TAX & $.006(1.7)$ & $.006(1.8)$ & $.005(1.5)$ & $.006(1.7)$ \\
\hline YR75 & $.058(3.9)$ & $.057(3.9)$ & $.057(3.9)$ & $.057(3.9)$ \\
\hline YR76 & $.117(8.3)$ & $.116(8.2)$ & $.116(8.2)$ & $.114(8.2)$ \\
\hline YR77 & $.169(12.2)$ & $.169(12.3)$ & .169 (122) & $.169(12.4)$ \\
\hline YR78 & $232(16.5)$ & $231(16.5)$ & $232(16.4)$ & $231(16.6)$ \\
\hline YR79 & $311(22.2)$ & $311(22.2)$ & $311(221)$ & $310(22.3)$ \\
\hline YR80 & 384 (26.9) & $384(27.0)$ & $383(26.8)$ & $383(27.1)$ \\
\hline T1 &. $.074(4.8)$ & $-.079(4.9)$ & $-.072(4.7)$ & $-.078(5.1)$ \\
\hline $\mathbf{T} 2$ & $-.013(0.9)$ & $-.017(1.1)$ & $-.012(0.5)$ & $-.018(1.1)$ \\
\hline $\mathbf{T 3}$ &. $.022(1.8)$ & $-.023(1.9)$ & $-.019(1.6)$ & $.021(1.8)$ \\
\hline T4 & $-.001(0.1)$ & $-.001(0.1)$ & $-.002(0.2)$ & $-.002(0.1)$ \\
\hline $\bar{R}^{2}$ & 808 & 809 & 808 & 811 \\
\hline
\end{tabular}

$\mathrm{n}=263$ in all equations

where:

TEN1

estimated probability of gaining tenure \}

TEN2

TEN3

estimated probabiilty of gaining tenure \} see Table 2 for precise

TEN5 estimated probability of gaining tenure \} definitions

BEN estimated probability of gaining tenure \}

RASSOC ratio of average associate to average assistant professor salary in the department in the year

PHD 1 = new assistant professor had a Ph.D, O=ABD

LMEDVAL logarithm of the median value of owner occupied housing in the city in 1979-80

TAX

YRJ average combined state income and sales tax rate at a $\$ 20,000$ adjusted gross income (in 1979 dollars) in the year

TJ $1=$ year j, $0=$ other (1974-75 is the omitted category)

UNSAL logarithm of Dew assistant professor starting salary in the department in the year

Sources: (A) Annual AEA Departmental Surveys - INSAL, RASSOC, PHD.

(B) American Association of University Professors (1980) - BEN.

(C) U.S. Bureau of the Census (1983) - LMEDVAL.

(D) Willis (1990) and Willis and Pieper (1993) - TEN1, TEN2, TEN4, TEN5.

(E) National Academy of Science (1982) - T1, T2, T3, T4.

(F) Feenberg and Rosen (1986) 
Table 4

Determinants of the Logarithm of Average Associate Professor Salaries and the Ratio of Average Assoclate to Average Assistant Professor Salaries in Economics Departments at Ph.D. Granting Institutions: American Economic Association 1974-75 to 1980-81 Sample (absolute value $t$ statistics)

\begin{tabular}{|c|c|c|c|c|}
\hline & \multicolumn{4}{|c|}{ Tenure Probabillty Coencients } \\
\hline & TEN1 & TEN2 & TEN3 & TENS \\
\hline $\begin{array}{l}\text { A) Logarithm of Associate } \\
\text { Professor Salaries }\end{array}$ & $\begin{array}{l}-.098 \\
(3.5)\end{array}$ & $\begin{array}{l}-.091 \\
(3.2)\end{array}$ & $(4.122)$ & $\begin{array}{l}. .101 \\
(3.7)\end{array}$ \\
\hline $\bar{R}^{2}$ & .727 & .725 & .734 & .729 \\
\hline $\begin{array}{l}\text { B) Ratio of Average Associate } \\
\text { to Average Assistant Professor } \\
\text { Salaries }\end{array}$ & $\begin{array}{l}-.176 \\
(5.5)\end{array}$ & $\begin{array}{l}-.157 \\
(4.8)\end{array}$ & $\frac{-.219}{(7.1)}$ & $\begin{array}{l}. .167 \\
(5.3)\end{array}$ \\
\hline $\mathbf{R}^{2}$ & .116 & .092 & 201 & .109 \\
\hline
\end{tabular}

- Also included in each equation were all of the variables from Table 3 save for PHD and RASSOC.

- Also included in each equation were year and tier dichotomous variables. 
Number of Observations on New Assistant Professors' Salaries at Ph.D. Granting Institutions During the 1974-75 to 1980-81 Perlod Used in the Analyser

\begin{tabular}{|c|c|c|c|}
\hline Deparment & $\begin{array}{l}\text { Number of } \\
\text { Observations }\end{array}$ & Deparment & $\begin{array}{l}\text { Number of } \\
\text { Observations }\end{array}$ \\
\hline The American University & 1 & University of Hawaii & 1 \\
\hline Arizona State Univ. & 8 & University of Houston & 1 \\
\hline University of Arkansas & 1 & University of Minois & 4 \\
\hline Boston College & 3 & Indiana University & 3 \\
\hline Boston University & 2 & University of lown & 1 \\
\hline Brown University & 2 & lowa State University & 6 \\
\hline Univ. of California & 3 & Johns Hopkins University & 2 \\
\hline Univ. of California-Davis & 5 & University of Kansas & 7 \\
\hline Univ. of Cal-Los Angeles & 2 & University of Kentucly & 6 \\
\hline Univ. of Cal.San Diego & 3 & Louisiana St. Univ.-Baton Rouge & 5 \\
\hline Univ. of Cal.Santa Barbara & 2 & University of Maryland & 1 \\
\hline Carnegie Mellon & 2 & Massachusetts Inst. of Tech. & 3 \\
\hline University of Chicago & 1 & University of Michigan & 4 \\
\hline Clark University & 2 & Michigan State University & 5 \\
\hline Univ. of Colorado & 1 & Univ. of Minnesota-Minneapolis & 2 \\
\hline Colorado State Univ. & 2 & University of Mississippi & 1 \\
\hline Univ. of Connecticut & 1 & University of Missouri & 6 \\
\hline Cornell University & 3 & University of Nebraska & 2 \\
\hline Duke University & 3 & Univ. of North Carolina & 2 \\
\hline Univ. of Florida & 5 & North Carolina State Univ. & 4 \\
\hline Florida State Univ. & 1 & Northwestern University & 3 \\
\hline George Washington Univ. & 2 & University of Notre Dame & 4 \\
\hline Georgetown University & 1 & Ohio State University & 4 \\
\hline University of Georgia & 4 & University of Otlahoma & 3 \\
\hline Georgia State Univ. & 3 & Otlahoma State Univ. & 4 \\
\hline Harvard University & 2 & Northeastern University & 5 \\
\hline
\end{tabular}


Appendix Table A1 (continued)

\begin{tabular}{|c|c|c|c|}
\hline Department & $\begin{array}{c}\text { Number of } \\
\text { Obsenvations }\end{array}$ & Department & $\begin{array}{c}\text { Number of } \\
\text { Obsenvations }\end{array}$ \\
\hline University of Oregon & 4 & Syracuse University & 6 \\
\hline Univ. of Pennsylvania & 5 & Temple University & 6 \\
\hline Pennsylvania State Univ. & 5 & University of Tennessee & 1 \\
\hline University of Pittsburgh & 2 & Texas A\&M University & 6 \\
\hline Princeton University & 6 & Tulane University & 1 \\
\hline Purdue University & 3 & University of Utah & 1 \\
\hline Rice University & 2 & Vanderbilt University & 2 \\
\hline University of Rochester & 2 & University of Virginia & 9 \\
\hline Rutgers University & 3 & Virginia Polytechnic Inst. & 2 \\
\hline St. Louis University & 3 & University of Washington & 5 \\
\hline Univ. of South Carolina & 3 & Washington State Univ. & 2 \\
\hline Univ. of Southern California & 5 & Washington University & 2 \\
\hline Southern Illinois University & 1 & Wayne State University & 5 \\
\hline Southern Mathodist Univ. & 5 & Univ. of Wisconsin-Madison & 5 \\
\hline Stanford University & 6 & University of Wyoming & 2 \\
\hline SUNY at Albany & 2 & Yale University & 5 \\
\hline SUNY at Binghamton & 1 & Yale University & 5 \\
\hline SUNY at Buffalo & 6 & & \\
\hline
\end{tabular}

- $86 \mathrm{Ph}$.D. granting departments provided 286 observations on starting assistant professor salaries during the $1974-75$ to $1980-81$ period. 